\title{
Nitrogen interception and export by experimental salt marsh plots exposed to chronic nutrient addition
}

\author{
Lindsay D. Brin ${ }^{1,2, *}$, Ivan Valiela ${ }^{2}$, Dale Goehringer ${ }^{3}$, Brian Howes ${ }^{3}$ \\ ${ }^{1}$ Brown University, Department of Ecology \& Evolutionary Biology, 80 Waterman Street, Box G-W, Providence, \\ Rhode Island 02912, USA \\ ${ }^{2}$ The Ecosystems Center, Marine Biological Laboratory, 7 MBL St., Woods Hole, Massachusetts 02543, USA \\ ${ }^{3}$ School of Marine Science and Technology, University of Massachusetts, Dartmouth, 706 South Rodney French Blvd., \\ New Bedford, Massachusetts 02744, USA
}

\begin{abstract}
Mass balance studies conducted in the 1970s in Great Sippewissett Salt Marsh, New England, showed that fertilized plots intercepted 60 to $80 \%$ of the nitrogen $(\mathrm{N})$ applied at several treatment levels every year from April to October, where interception mechanisms include plant uptake, denitrification and burial. These results pointed out that salt marshes are able to intercept land-derived $\mathrm{N}$ that could otherwise cause eutrophication in coastal waters. To determine the long-term $\mathrm{N}$ interception capacity of salt marshes and to assess the effect of different levels of $\mathrm{N}$ input, we measured nitrogenous materials in tidal water entering and leaving Great Sippewissett experimental plots in the 2007 growing season. Our results, from sampling over both full tidal cycles and more intensively sampled ebb tides, indicate high interception of externally added $\mathrm{N}$. Tidal export of dissolved inorganic $\mathrm{N}$ (DIN) was small, although it increased with tide height and at high $\mathrm{N}$ input rates. $\mathrm{NH}_{4}{ }^{+}$export was generally 2 to 3 times $\mathrm{NO}_{3}{ }^{-}$export, except at the highest $\mathrm{N}$ addition, where DIN export was evenly partitioned between $\mathrm{NO}_{3}{ }^{-}$and $\mathrm{NH}_{4}{ }^{+}$. Exports of dissolved organic $\mathrm{N}$ were not enhanced by $\mathrm{N}$ addition. Overall, export of added $\mathrm{N}$ was very small, $<7 \%$ for all treatments, which is less than earlier estimates. Apparent enhanced tidal export of $\mathrm{N}$ from $\mathrm{N}$-amended plots ceased when $\mathrm{N}$ additions ended in the fall. Nitrogen cycling within the vegetated marsh appears to limit $\mathrm{N}$ export, such that interception of added $\mathrm{N}$ remains high even after over 3 decades of external $\mathrm{N}$ inputs.
\end{abstract}

KEY WORDS: Spartina salt marsh · New England · Nutrient addition · Nitrogen export · Nitrogen uptake · Dissolved inorganic nitrogen · Dissolved organic nitrogen $\cdot$ Nitrate $\cdot$ Ammonium

Resale or republication not permitted without written consent of the publisher

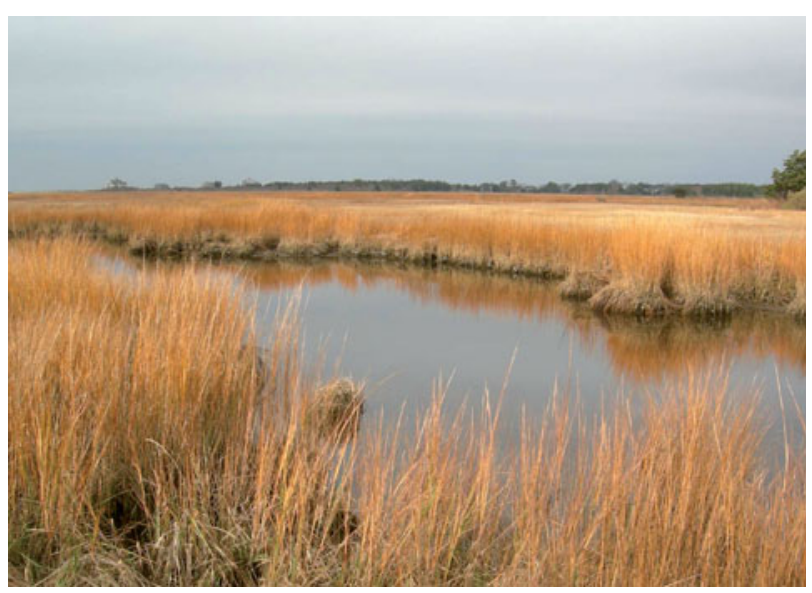

Salt marshes limit the amount of land-derived nitrogen carried by ebbing tides out to receiving coastal waters

Photo: Ivan Valiela

\section{INTRODUCTION}

Salt marshes provide important ecological services in coastal settings, including interception of landderived nitrate $\left(\mathrm{NO}_{3}{ }^{-}\right)$and export of energy-rich reduced nitrogen $\left(\mathrm{NH}_{4}{ }^{+}\right.$or dissolved organic nitrogen [DON]) (Valiela 1983). Urbanization in coastal watersheds has increased land-derived nitrogen $(\mathrm{N})$ loads - primarily as $\mathrm{NO}_{3}{ }^{-}$- to coastal waters worldwide (McClelland \& Valiela 1998, Cloern 2001, Valiela $\&$ Bowen 2002). These mainly anthropogenic $\mathrm{N}$ loads (Valiela et al. 1997) have led to eutrophication and associated detrimental effects in estuaries and other shallow coastal waters (Baden et al. 1990, Valiela et al. 
1990, 1992). Land-derived $\mathrm{N}$ loads may be intercepted by fringing salt marshes located between terrestrial sources of $\mathrm{N}$ and downstream ecosystems (Howes et al. 1996). In particular, biologically active $\mathrm{NO}_{3}{ }^{-}$can be intercepted within salt marshes by plant uptake, denitrification and burial (White \& Howes 1994, Valiela \& Cole 2002); at the ecosystem level, much interception is through creek-bottom microbial processes (Howes et al. 1996, Hamersley \& Howes 2003).

In earlier work in Great Sippewissett salt marsh, MA, Valiela et al. (1973) showed that salt marsh plots receiving moderate levels of $\mathrm{N}$ addition for 2 to 3 yr were exporting 20 to $40 \%$ of added $\mathrm{N}$, while the remaining 60 to $80 \%$ was intercepted. It has since been demonstrated that experimental plots had increased denitrification rates (Hamersley \& Howes 2005) and increased $\mathrm{N}$ uptake by plants, leading to greater biomass and also a higher percentage of $\mathrm{N}$ in the biomass (Valiela et al. 1975, Vince et al. 1981). However, denitrification rate in estuaries has been shown to increase to an asymptote, and as $\mathrm{N}$ input increases, the percent of $\mathrm{N}$ input that is removed by denitrification often decreases (Seitzinger 1990, Valiela 1995). Assuming that there is a biological limit to the seasonal amount of denitrification and plant biomass $\mathrm{N}$ storage that can occur in salt marsh plots over a growing season, the degree to which the interception capability could extend to greater amounts of $\mathrm{N}$ is uncertain.

Furthermore, because anthropogenic, land-derived $\mathrm{N}$ loading to natural marshes is continuing indefinitely, the question was also raised as to whether the interception capability of these experimental plots could be sustained under chronic, long-term, external $\mathrm{N}$ loading, or whether this capacity might be degraded. As salt marshes mature, they may shift from net import to net export of dissolved and particulate matter (Dame \& Allen 1996); however, this is over very long time scales and not necessarily in response to $\mathrm{N}$ loading, leaving open the question of the longevity of the salt marsh ecosystem service of $\mathrm{N}$ interception.

In the present study, we investigated the long-term ability of salt marshes to intercept chronically added $\mathrm{N}$, as well as the potential effect of input rates on interception and export. To do so, we conducted a 2-part study of the experimental salt marsh plots at Great Sippewissett salt marsh, which have received $\mathrm{N}$ additions at different fertilization rates approximately biweekly during the growing season for over 3 decades. We first investigated the pattern of $\mathrm{N}$ import and export over the entire tidal cycle by measuring nutrient concentrations of flood and ebb water exchanging through the tidal creek that bisects each experimental plot. Second, we conducted time-course sampling of $\mathrm{NO}_{3}{ }^{-}, \mathrm{NH}_{4}{ }^{+}$and $\mathrm{DON}$ in ebbing tidal water, and used tidal volumes to determine the mass of
$\mathrm{N}$ exported from each replicate plot for all treatments. These periodic field surveys were coupled with a plotspecific tidal volume approach to estimate dissolved inorganic N (DIN) export over the growing season. To better refine the level of $\mathrm{N}$ retention, estimates of seasonal export from $\mathrm{N}$ addition plots were compared to parallel estimates for unamended control plots to determine the mass of $\mathrm{N}$ exported relative to the amount of $\mathrm{N}$ applied.

\section{MATERIALS AND METHODS}

Study site. We sampled 10 experimental plots in Great Sippewissett salt marsh, Falmouth, MA (Valiela et al. 1973). The plots are $10 \mathrm{~m}$ in radius and bisected by small creeks, which are connected to Buzzards Bay via a main creek (Fig. 1). Plots were established in sites containing creek-bed, creek banks, low marsh and high marsh habitats. Species composition of the vegetation has been mapped over the decades of study (Valiela et al. 1985, Rogers et al. 1998, Fox 2007), and we can generalize that tall-form Spartina alterniflora grows on creek banks, while intermediate and shortform $S$. alterniflora grows in low marsh areas. High marsh habitats are dominated by S. patens and Distichlis spicata, and some $S$. alterniflora and Iva frutescens may also be present (Hersh 1996, Fox 2007).

We examined 2 replicate plots of 5 treatment levels, for a total of 10 plots. Control (C), low fertilization (LF)

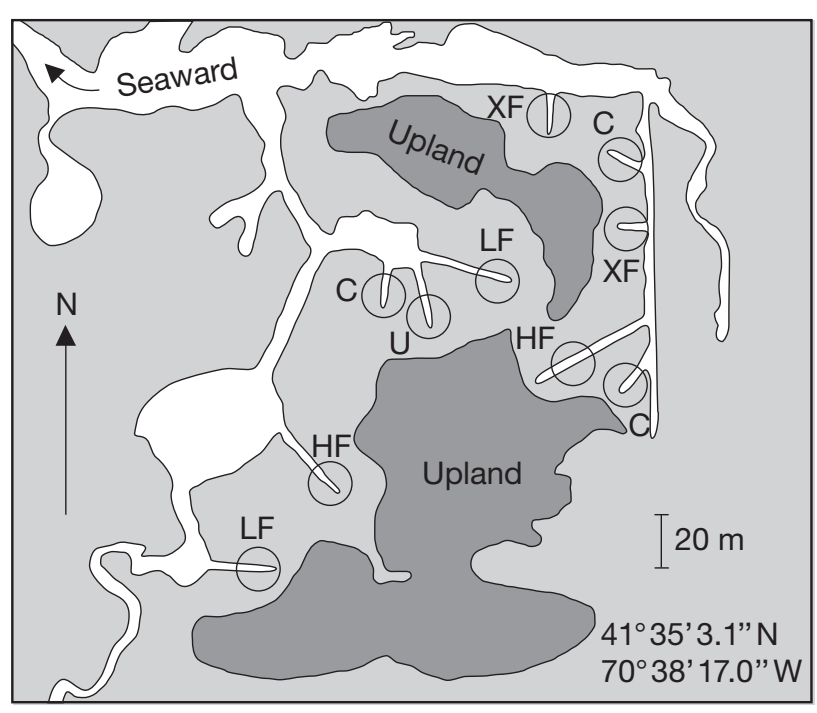

Fig. 1. Experimental plots in Great Sippewissett salt marsh. Plots labeled $\mathrm{C}$ are controls; the other plots were fertilized with mixed NPK fertilizer (low fertilization [LF]: 0.9; high fertilization [HF]: 2.6; extra-high fertilization [XF]: $7.8 \mathrm{~g} \mathrm{~N} \mathrm{~m}^{-2}$ $\mathrm{wk}^{-1}$ ) or just urea (U: $2.6 \mathrm{~g} \mathrm{~N} \mathrm{~m}^{-2} \mathrm{wk}^{-1}$ ) and superphosphate. Upland areas are wooded. Modified from Fox (2007) 
and high fertilization (HF) plots were established in 1970, urea (U) plots in 1971 and extra-high fertilization (XF) plots in 1974 (Fig. 1). Fertilization treatments were, and continue to be, applied to each plot approximately every 2 wk throughout the April to October growing season. LF, HF and XF plots receive a mixed fertilizer sold commercially as Milorganite supplemented with enough urea to be $10 \% \mathrm{~N}, 6 \% \mathrm{P}$ and $4 \% \mathrm{~K}$. Fertilizer levels were set at 10, 30 and 90 times the recommended annual dosage for oats $\left(0.9,2.6\right.$ and $7.8 \mathrm{~g} \mathrm{~N} \mathrm{~m}^{-2} \mathrm{wk}^{-1}$, respectively); over the season, this amounts to approximately 0.7, 2.2 and 6.5 times the annual short Spartina alterniflora $\mathrm{N}$ demand, respectively (White \& Howes 1994). Urea plots received the same amount of $\mathrm{N}$ as $\mathrm{HF}$ plots, but entirely as urea instead of mixed fertilizer. Furthermore, one half of each plot also received $\mathrm{P}$ as superphosphate; this treatment was designed to examine the effect of $\mathrm{N}$ alone. In earlier studies, the effects of $\mathrm{N}$ alone were indistinguishable from those of the mixed fertilizer (Valiela et al. 1985).

Sampling phase 1: full tidal cycles. To define the time course of nutrient concentrations of tidal water entering and leaving the experimental plots during entire tidal cycles, we took hourly water samples over the course of a tidal cycle at the mouth of the creek in each plot. During each flood tide, water level increased in the creeks before spilling onto the marsh platform, and the reverse occurred at ebb tide. We began sampling at low tide, continued through flood and ebb tide, and finished when water stopped flowing out of each creek. Sample salinity was measured with a refractometer, and samples were filtered and then stored in acid-washed bottles on ice until taken to the laboratory. Samples were analyzed for $\mathrm{NO}_{3}{ }^{-}$and $\mathrm{NH}_{4}{ }^{+}$concentration using a Lachat Autoanalyzer (QuikChem FIA +8000 series) and standard colorimetric methods for brackish water samples (Flow injection analysis: QuikChem Method 31-107-04-1-E for $\mathrm{NO}_{3}{ }^{-}$and QuikChem Method 31-107-06-1-B for $\mathrm{NH}_{4}{ }^{+}$). This sampling program was carried out twice during June and July 2007. Both sampling dates were $10 \mathrm{~d}$ after the most recent fertilization, and predicted high tide heights for both dates were within $1 \mathrm{SD}$ of the mean of all predicted high tide heights over the fertilization period.

To describe the time course of the tide, tide height was measured using a meter stick attached to a permanent tide stake in each plot. To convert tide height measurements to absolute height above mean sea level (MSL), the elevation of the base of each tide stake relative to MSL was determined by use of a Trimble GPS unit (Trimble 4800 receivers, Project Datum NAD1983 [Conus], Geoid Model GEOID99 [Conus]); 3 measurements were taken at each point and an average elevation was used to convert measured tide heights to MSL values.
Sampling phase 2: export and interception of $\mathrm{NH}_{4}{ }^{+}$, $\mathrm{NO}_{3}{ }^{-}$and DON. Ebb tide sampling: The similarity of flood tide nutrient concentrations between treatments, as revealed in the Phase 1 results, indicated that analysis of ebb tides associated with control and treated plots was sufficient to determine the $\mathrm{N}$ loss resulting from $\mathrm{N}$ amendment. This simplification of approach allowed for additional data collection across a variety of tide heights and weather conditions to capture the large variation in nutrient concentrations and tidal volumes due to seasonal changes and other environmental factors. Eleven tides were sampled between August and November 2007; 9 were sampled during the fertilization period and 2 were sampled in November, to determine whether $\mathrm{N}$ export continued after fertilization ceased for the year. Water sampling was conducted at 20 min intervals throughout each ebb tide, from high slack until there was no longer tidewater outflow from the creek in each plot. Water samples were integrated throughout the water column, with care taken to avoid any potential freshwater at the surface and porewater just above the sediment. Salinity and tide height were measured and recorded for each sample, and samples were collected, stored and analyzed as described above. In addition, on 3 dates in August and November, samples were analyzed for DON concentrations using a Lachat Autoanalyzer (QuikChem FIA+ 8000 series) on persulfate digested samples with correction for $\mathrm{NO}_{3}{ }^{-}$content (D'Elia et al. 1977). These 3 dates were chosen to represent the approximate degree of DON export during and after the growing season (August and November) because they had near-average high tide heights, which our DIN analysis showed to be an important factor in determining export.

Estimation of tidal volumes: To calculate export of $\mathrm{NO}_{3}{ }^{-}$and $\mathrm{NH}_{4}{ }^{+}$, we needed not only measurements of nutrient concentration, but also estimates of tidal water exchange. To measure tidal volume, we used a detailed description of the topography of each plot as well as the tide height at the time of each sample. To define the elevation of each plot, we entered detailed contour maps of each plot into ArcGis 9.1 (ESRI), and interpolated data to create files with approximately 7800 northing, easting, and elevation points for each plot (L. Fox unpubl. data). The relative elevations from these data files were corrected to elevation above MSL by comparing the elevations of several known points with measurements taken with a Trimble GPS unit, as described above. From the elevation data files, we also determined geometric mean elevation above MSL of each plot.

To calculate the volume of water above a plot for any given tide height, we created a MATLAB program (MATLAB 6.5.0.180913a, Release 13; MathWorks) that 
used as input the tide height on the plot relative to MSL, determined the height of water above each point in the elevation data file for that plot, estimated the area that each point represented, used water height and representative point area to calculate an approximate volume and summed these volumes to approximate total water volume.

Horizontal flow between the creek bank and salt marsh sediment is negligible compared to these modeled flow volumes. Porewater draining from creek banks has been found to be a small fraction of the hydrologic budget of vegetated marsh sediments in Great Sippewissett salt marsh (Howes \& Goehringer 1994). Furthermore, flood tidal water enters marsh sediments virtually entirely to replace water lost by evapotranspiration, and there is minimal transfer to adjacent tidal creeks (Dacey \& Howes 1984).

Calibration of flux model: We assessed the accuracy of the tidal volume calculated from the topographic model for each of the plots by comparison with measured flows in late October 2008. In each plot, ebb tidal volume was directly measured from a time series of water velocity and wetted cross-sections of each creek where it enters the plot at the seaward edge. Flow was measured by a Marsh McBirney electromagnetic flow meter (FlowMate 2000) on a top-setting wading rod. Velocities were measured using open channel flow measurement techniques, with multiple measurements across the tidal channel. Due to the channel configurations and vegetation growing within some of the creeks, accurate flow measurements, and therefore calibrations, could be made on only 7 of the 10 plots, but did include at least 1 replicate from each treatment.

Export calculations: To determine the amount of DIN or DON exported from each plot over each sampled ebb tide, we multiplied measured nutrient concentrations by the estimated water volume leaving each plot over the relevant sampling interval, and these values were summed for a total export over the ebb tide. Specifically, the volume multiplier for a single sample was calculated as the average of the water volumes over the plot during the previous and the current samples, minus the average of the water volumes over the plot during the current and the subsequent sample. For example, the amount of $\mathrm{N}_{\text {as }} \mathrm{NO}_{3}{ }^{-}$lost for sample $y$ was calculated as:

$\left[\mathrm{NO}_{3}{ }^{-}\right]_{Y} \times\left[\operatorname{average}\left(\mathrm{vol}_{y-1}, \mathrm{Vol}_{Y}\right)-\operatorname{average}\left(\mathrm{vol}_{y}, \mathrm{vol}_{y+1}\right)\right]$ where $\left[\mathrm{NO}_{3}{ }^{-}\right]_{Y}$ is the concentration of $\mathrm{NO}_{3}{ }^{-}$in water sample $y, \operatorname{vol}_{Y}$ is the water volume on the plot at the time of sample $y, \mathrm{vol}_{y-1}$ is the water volume on the plot at the previous sampling time and $\operatorname{vol}_{Y+1}$ is the water volume on the plot at the subsequent sampling time. For the first sample, the volume of water at high tide was used in place of the first average, and for the last sample, the volume of water left on the plot at low tide was used in place of the second average.

Estimation of DIN export over the fertilization period. The calculations described so far provided estimates of $\mathrm{N}$ export during the tides that were actually sampled. These data were extrapolated to the rest of the experimental period, with the assumption that the sampled tides were representative of the tides during the fertilization period, April to October. To test this assumption, we compared the frequency distribution of tide heights on our sampling days to the distribution over the entire fertilization period using a $\chi^{2}$ goodnessof-fit test.

To estimate DIN export over the fertilization period, we first determined the history of tide heights for Great Sippewissett salt marsh for April to October. This was accomplished by relating available predictions of tide heights for an adjacent site, West Falmouth Harbor, to a series of tide heights that we measured at Great Sippewissett salt marsh. We obtained tide height predictions for West Falmouth Harbor, $1 \mathrm{~km}$ north of Great Sippewissett salt marsh, from XTide version 2.8.2 (Flater 1998). To obtain measurements of actual tide heights in Great Sippewissett salt marsh, we used Onset HOBO Water Level Loggers, which use ambient pressure, adjusted to account for barometric pressure, to determine water height. The water level loggers were deployed at several sites in Great Sippewissett salt marsh, including one located in the high marsh to record barometric pressure and one at a low point at the mouth of an experimental plot, throughout September 2007.

\section{RESULTS}

\section{Changes in nutrient concentration across entire tidal cycles}

Concentrations of nitrate and ammonium changed substantially (Fig. 2b,c) as tide water flooded onto and ebbed from the experimental plots (Fig. 2a). There was variation among plots subject to the different fertilization treatments, but in general, $\mathrm{NO}_{3}{ }^{-}$concentrations were initially relatively low, and increased somewhat in flooding seawater. This pattern suggests that the shallow layer of leading flood water initially picked up nutrients as it moved onto the marsh plots. As larger volumes of water flooded the plots, dilution occurred, which led to near-minimum concentrations at the highest tide heights (Fig. 2b). As water ebbed, there was a substantial increase in $\mathrm{NO}_{3}{ }^{-}$concentration in water leaving the more highly fertilized plots, peaking at mid-ebb and subsequently decreasing as the ebb tide proceeded (Fig. 2b). 

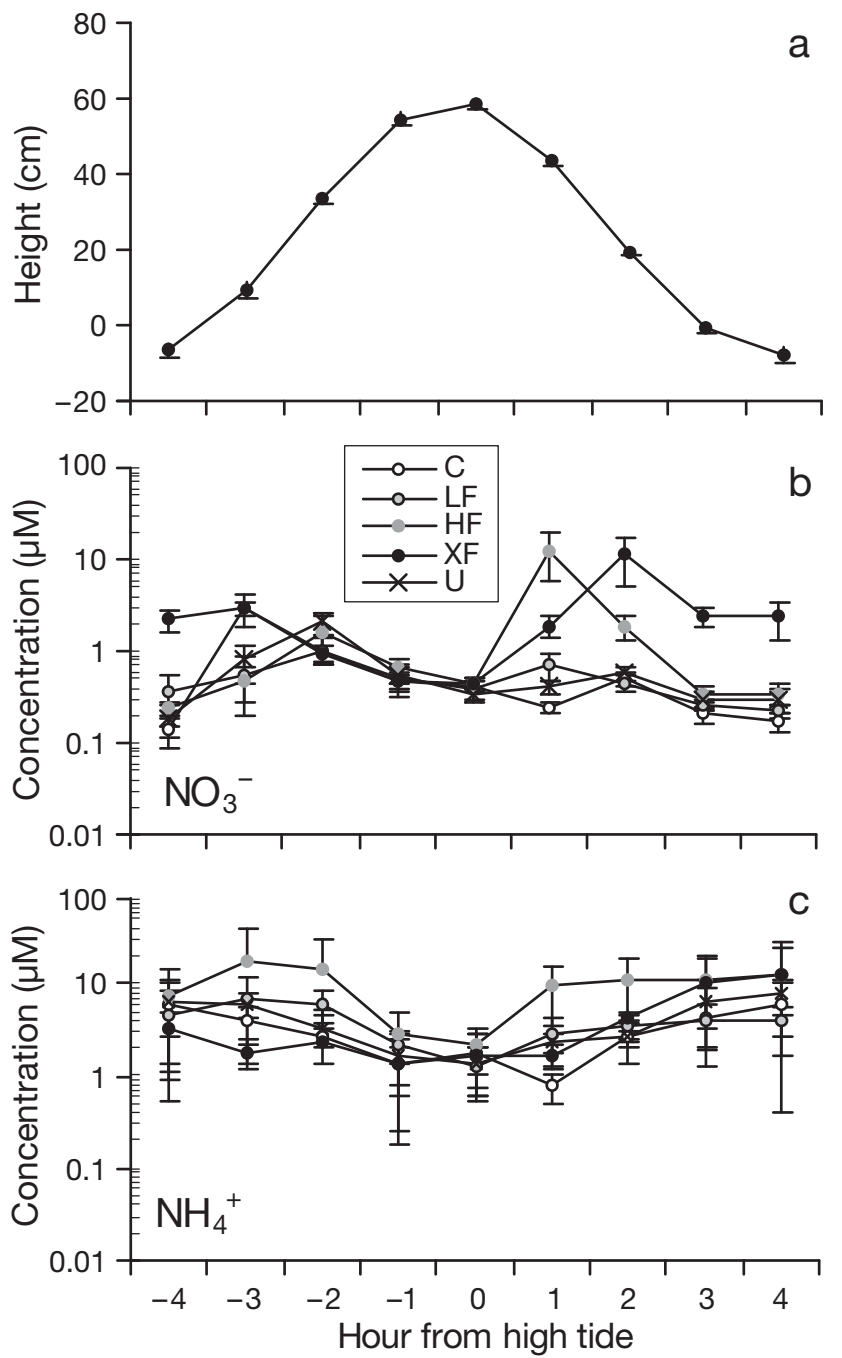

Fig. 2. Mean ( $\pm \mathrm{SE}$ ) (a) tide height, (b) $\mathrm{NO}_{3}{ }^{-}$concentration and (c) $\mathrm{NH}_{4}{ }^{+}$concentration in water on plots subject to each fertilization treatment for full tidal cycle sampling. Data are averaged over both sampling dates

The concentration of $\mathrm{NH}_{4}{ }^{+}$in flooding water became lower with the incoming tide, reached a minimum or near-minimum at high tide and then increased as the ebb tide proceeded (Fig. 2c). The high $\mathrm{NH}_{4}^{+}$concentrations in the residual tidal water before and after the high tide likely derived from mixing with $\mathrm{NH}_{4}{ }^{+}$-rich porewater.

Several notable features were apparent in the time courses of both $\mathrm{NO}_{3}{ }^{-}$and $\mathrm{NH}_{4}{ }^{+}$concentrations across the tidal cycle. First, concentrations of $\mathrm{NO}_{3}{ }^{-}$and $\mathrm{NH}_{4}{ }^{+}$ in flood water were similar among fertilization treatments (Fig. 3, left) (Kruskal-Wallis test, $\mathrm{NO}_{3}^{-}: \mathrm{p}=0.380$, $\left.\mathrm{NH}_{4}{ }^{+}: \mathrm{p}=0.468\right)$, showing that flooding seawater had consistent concentrations of DIN across the salt marsh.

Second, for $\mathrm{C}$ plots and plots receiving low $\mathrm{N}$ inputs, concentrations of $\mathrm{NO}_{3}{ }^{-}$and $\mathrm{NH}_{4}{ }^{+}$in flood and ebb water were not significantly different, except that $\mathrm{NO}_{3}{ }^{-}$ concentrations in flood water were higher than in ebb water for C plots (Kruskal-Wallis test, $\mathrm{p}=0.021$ ). This suggests that there may have been a small net tidal import of $\mathrm{NO}_{3}{ }^{-}$to $\mathrm{C}$ plots. In contrast, concentrations of both $\mathrm{NO}_{3}{ }^{-}$(HF plots: $\mathrm{p}=0.018$, XF plots: $\mathrm{p}=0.009$ ) and $\mathrm{NH}_{4}{ }^{+}$(HF plots: $\mathrm{p}=0.002$, XF plots: $\mathrm{p}=0.011$ ) were higher in ebb water than in flood water for HF and XF plots. These results therefore suggest that unamended salt marsh plots intercepted $\mathrm{NO}_{3}{ }^{-}$to some degree, and that highly amended plots ( $\mathrm{HF}$ and XF) exported both $\mathrm{NO}_{3}{ }^{-}$and $\mathrm{NH}_{4}{ }^{+}$in some proportion to input rates.

\section{Intensive (time-course) ebb tide sampling}

The results of the whole tidal cycle sampling showed that there were substantial tidal water concentration differences among treatments that could lead to differences in nutrient export, and that these differences were manifest mainly during ebb tides, in water about to leave the plots (Fig. 3). We now move on to the second sampling phase of our research, in which we used data from ebb tides sampled more intensively to quantify $\mathrm{NO}_{3}{ }^{-}$and $\mathrm{NH}_{4}{ }^{+}$export, from which we could estimate within-plot interception. It seemed reasonable to concentrate on a more intensive sampling during ebb tides because flood water DIN concentrations, although variable, had a consistent range and variation among the different plots (Fig. 3, left).

\section{Export of $\mathrm{NO}_{3}{ }^{-}$and $\mathrm{NH}_{4}{ }^{+}$}

There was substantial variation in the concentrations of both $\mathrm{NO}_{3}{ }^{-}$and $\mathrm{NH}_{4}{ }^{+}$during the intensively sampled ebb tides. Analysis across all fertilization regimes showed that this variation was not due to season (Brin 2008). The large scatter in the concentrations overwhelmed whatever seasonal trends might be present.

There were evident differences in $\mathrm{NO}_{3}{ }^{-}$and $\mathrm{NH}_{4}{ }^{+}$ concentrations in ebb tidal water associated with the different treatments (Brin 2008). Because the concentrations were highly skewed, we examined median and maximum concentrations, both of which increased with higher $\mathrm{N}$ inputs (Kruskal-Wallis test, $\mathrm{p}<0.001$ ).

To allow comparison of DIN exports between treatments, we calculated $\mathrm{NO}_{3}{ }^{-}$and $\mathrm{NH}_{4}{ }^{+}$export by multiplying concentration data by associated water volumes derived from the detailed topographic model. This procedure produced export values for each sample point which were then summed to determine export of each constituent over the complete ebb tidal period. The resulting export per tide was used to evaluate the relative relationships of fertilization rate, time since appli- 
cation of fertilizer and tide height with tidal export of $\mathrm{NO}_{3}{ }^{-}$and $\mathrm{NH}_{4}{ }^{+}$.

Fertilization rate. During the period of application of fertilizer, exports of $\mathrm{NO}_{3}{ }^{-}$and $\mathrm{NH}_{4}{ }^{+}$were higher in plots treated with higher dosages (Fig. 4, left) (linear regression using log-transformed values, $\mathrm{NO}_{3}{ }^{-}: \mathrm{p}<0.001$, $\mathrm{NH}_{4}{ }^{+}: \mathrm{p}=0.008$, DIN: $\mathrm{p}<0.001$; without $\mathrm{U}$ plots, $\mathrm{NO}_{3}{ }^{-}: \mathrm{p}<0.001, \mathrm{NH}_{4}{ }^{+}: \mathrm{p}=0.01$, DIN: $\mathrm{p}<0.001$ ). Export of $\mathrm{NO}_{3}{ }^{-}$and $\mathrm{NH}_{4}{ }^{+}$was of similar magnitude in plots receiving high $\mathrm{N}$ additions (Fig. 4, left). Export of DIN was small but measurable from plots receiving low or no experimental input (Fig. 4, left), but because export measurements did not include tidal import, this minimal tidal DIN export may be from the small amount of $\mathrm{N}$ carried onto the plots by the flooding tide (Fig. 3, left).

Time since fertilization. During the fertilization period, sampled tides ranged from 1 to $19 \mathrm{~d}$ after the most recent fertilization. Nonetheless, there was no significant relationship between export of $\mathrm{NO}_{3}{ }^{-}$or $\mathrm{NH}_{4}{ }^{+}$and number of days since the most recent fertilization (Brin 2008), implying that other factors had a greater effect on variation of DIN export.

Export of $\mathrm{NO}_{3}^{-}$and $\mathrm{NH}_{4}{ }^{+}$diminished markedly soon after experimental fertilization ended (Fig. 4, right). This change suggested that it was unlikely that there was sustained year-round tidal export of experimentally added $\mathrm{N}$ from the plots, which allowed us to constrain our estimates of treatment-related $\mathrm{N}$ export to the fertilization period.

Tide height effects. Different volumes of water flooded each plot at any given tidal height, owing to differences in elevation of plots relative to MSL. To account for these differences, we defined 'effective tide height' as the difference between high tide height relative to MSL and geometric mean elevation of the plot relative to MSL (Brin 2008 and associated Appendix 1).

In all fertilization treatments, $\mathrm{NO}_{3}{ }^{-}$and $\mathrm{NH}_{4}{ }^{+}$ export from plots increased in relation to the effective tide height (Fig. 5). This greater export of $\mathrm{N}$ by greater tidal volumes may be a result of increased time of tidal submergence of the plots. Furthermore, the increase in export with effective tide height was greatest for XF plots, as demonstrated by the slope of this relationship (Fig. 5). These results suggest that salt marshes subject to larger external inputs of $\mathrm{N}$ will export proportionally larger amounts of DIN to downstream waters, although the fraction exported will be small.

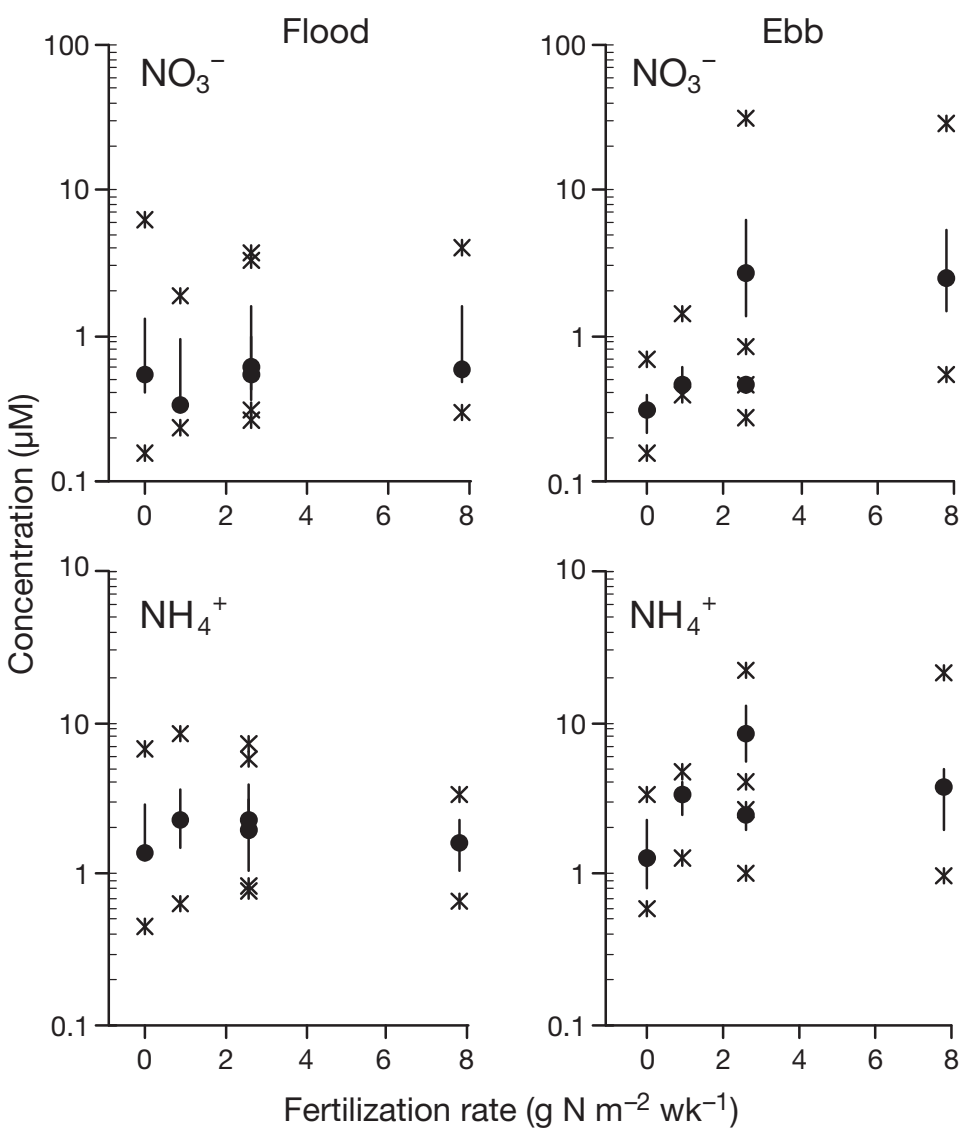

Fig. 3. $\mathrm{NO}_{3}{ }^{-}$and $\mathrm{NH}_{4}{ }^{+}$concentrations in flood and ebb water during full tidal cycles. Dots show medians, vertical lines show first and third quartiles, and asterisks show minimum and maximum concentrations, by treatment. Treatments are $\mathrm{C}, \mathrm{LF}, \mathrm{U}, \mathrm{HF}$ and $\mathrm{XF}$, which received 0.0, $0.9,2.6,2.6$ and $7.8 \mathrm{~g} \mathrm{~N} \mathrm{~m}^{-2} \mathrm{wk}^{-1}$, respectively. Median ebb water concentrations were higher on HF plots than on U plots. See 'Results' for statistics

\section{Export of DON}

DON analysis of samples from the 3 analyzed sampling dates showed that DON export was highly variable, and constituted approximately 80 to $90 \%$ of gross total dissolved $\mathrm{N}$ (TDN) export from $\mathrm{C}$ plots and approximately 10 to $75 \%$ of gross TDN from XF plots. This is a measurement of gross rather than net export, because it included any DON present in the water of the incoming tide, which may or may not have been variable throughout the marsh and among sampling dates. A comparison between fertilized and control plots indicated that DON export from the $\mathrm{N}$-amended plots was equal to or less than export from the control plots (Table 1). Although there were no significant differences between treatments within this data set, there was a trend towards decreased gross DON export from XF plots. This suggests that an estimate of dissolved $\mathrm{N}$ loss based upon DIN measurements is more likely to overestimate than underestimate the amount of treat- 
ment $\mathrm{N}$ exported, and can thus be used to constrain the upper limit of $\mathrm{N}$ export and the lower limit of $\mathrm{N}$ retention.

\section{Estimates of $\mathbf{N}$ export over the experimen- tal period relative to $\mathrm{N}$ inputs}

To estimate the magnitude of DIN export from the salt marsh plots and compare this export to the total amount of $\mathrm{N}$ added, we extrapolated export data from the sampled tides to the entire series of tides over the fertilization period (April-October). To allow extrapolation of export data over the fertilization period, we first tested the assumption that tide heights on our sampling days were representative of the tides that occurred during the entire fertilization period. No significant difference between frequency distributions of these 2 sets of tide heights was evident $\left(\chi^{2}\right.$ goodness-of-fit test, $\mathrm{p}=0.47$ ). Second, we tested whether high tide heights measured in Great Sippewissett salt marsh could be represented by available high tide height predictions for West Falmouth Harbor, and found that the relationship between these 2 sets of tide height data was highly significant $\left(F_{1,62}=1037.5, \mathrm{p}<0.001, \mathrm{r}^{2}=0.94\right)$ (Fig. 6). This result was expected, given the proximity of the tide stations and the absence of tidal restrictions in both systems.

Based upon the results of the tidal analysis, we used 2 methods to calculate the export of $\mathrm{NO}_{3}{ }^{-}$and $\mathrm{NH}_{4}{ }^{+}$from the experimental plots over the fertilization period. First, we used the linear regressions of $\mathrm{NO}_{3}{ }^{-}$and $\mathrm{NH}_{4}{ }^{+}$export against effective tide height (Fig. 5), and the history of tide heights in Great Sippewissett salt marsh as estimated from tide heights in West Falmouth Harbor (Fig. 6), to reconstruct the likely export of $\mathrm{NO}_{3}{ }^{-}$and $\mathrm{NH}_{4}{ }^{+}$for each tide and plot, and we then averaged export between plots for each treatment (Fig. 7). We then summed across all tides to calculate cumulative exports of $\mathrm{NO}_{3}{ }^{-}$and $\mathrm{NH}_{4}{ }^{+}$from each plot over the fertilization period, and averaged export between plots for each treatment (Fig. 8, Table 2).

With this linear regression method, the tight positive relationship between tide height and DIN export inherent in the regression equations is visible as the coupling of $\mathrm{NO}_{3}{ }^{-}$ and $\mathrm{NH}_{4}{ }^{+}$export to tide phases, with higher exports during high tides (Fig. 7). One of the
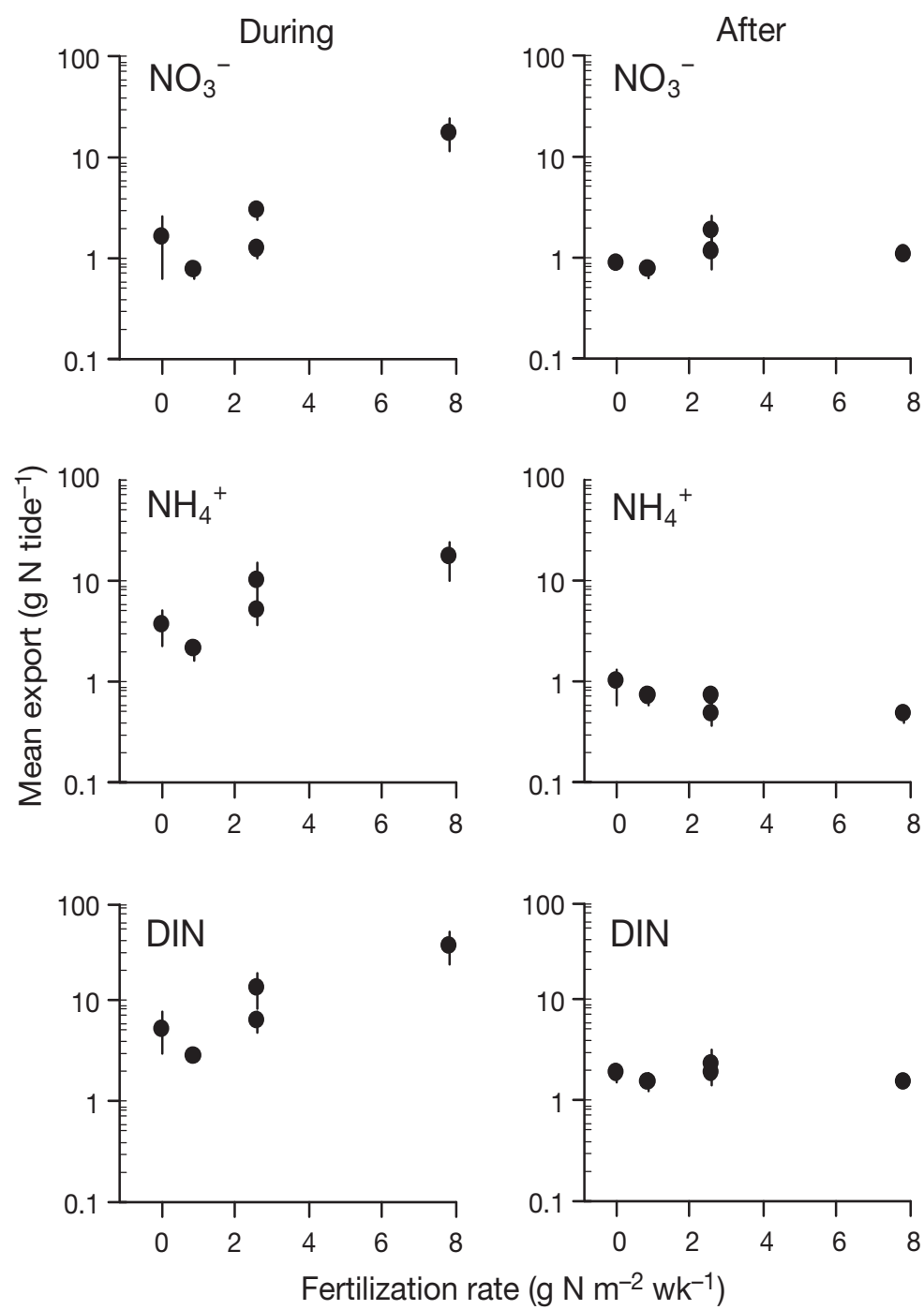

Fig. 4. Mean $( \pm \mathrm{SE})$ measured export per tide of $\mathrm{NO}_{3}{ }^{-}, \mathrm{NH}_{4}{ }^{+}$and dissolved inorganic nitrogen (DIN) from plots receiving each treatment, during and after the fertilization period. A log scale is used due to the log-normal distribution of the data. Mean exports were higher from HF plots than from $\mathrm{U}$ plots, except for $\mathrm{NH}_{4}{ }^{+}$export after the fertilization period. See Table 1 for treatment abbreviations and levels

Table 1. Gross export of dissolved organic nitrogen (DON) for several representative sample dates during and after the fertilization period. Mean $( \pm \mathrm{SE})$ exports are over 2 plots for each treatment. C: control; LF: low fertilization; U: urea; HF: high fertilization; XF: extra-high fertilization

\begin{tabular}{|lcccc|}
\hline \multirow{2}{*}{$\begin{array}{l}\text { Treatment } \\
\left(\mathrm{g} \mathrm{N} \mathrm{m} \mathrm{N}^{-2} \mathrm{wk}^{-1}\right)\end{array}$} & August 13 & August 31 & November 27 & Mean \\
\cline { 2 - 5 } $\mathrm{C}(0)$ & $29.9 \pm 8.5$ & $38.4 \pm 11.3$ & $16.1 \pm 11.3$ & $28.2 \pm 6.2$ \\
$\mathrm{LF}(0.9)$ & $33.9 \pm 7.0$ & $48.0 \pm 4.1$ & $28.2 \pm 2.5$ & $36.7 \pm 4.3$ \\
$\mathrm{U}(2.6)$ & $24.5 \pm 1.4$ & $31.7 \pm 0.8$ & $12.4 \pm 6.7$ & $22.9 \pm 4.0$ \\
HF (2.6) & $18.3 \pm 7.6$ & $32.0 \pm 8.8$ & $12.0 \pm 3.8$ & $20.8 \pm 4.9$ \\
XF (7.8) & $15.0 \pm 0.7$ & $20.0 \pm 9.7$ & $3.3 \pm 0.4$ & $12.8 \pm 4.0$ \\
\hline
\end{tabular}



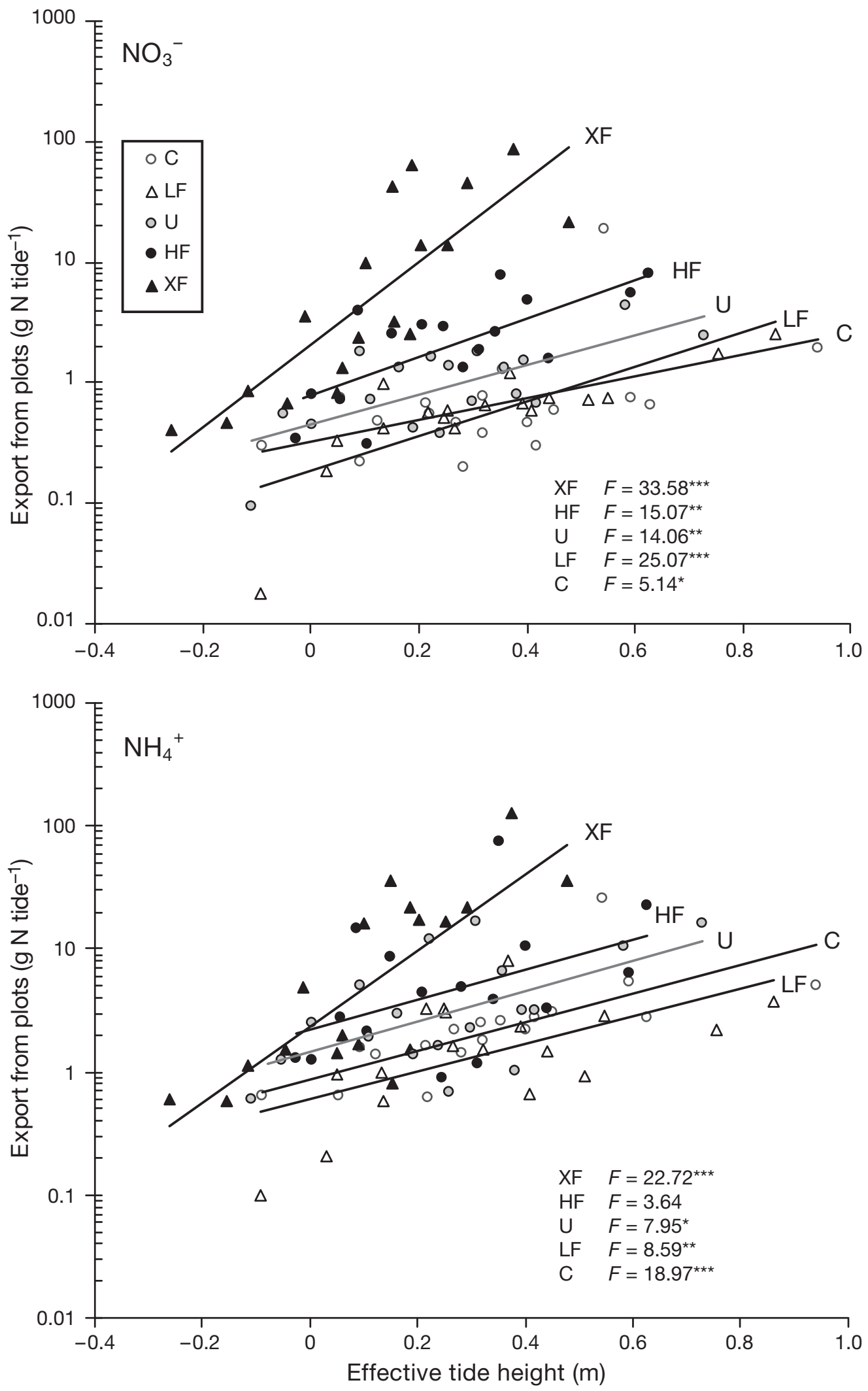

Fig. 5. Linear regressions of nitrogen export as $\mathrm{NO}_{3}{ }^{-}$and $\mathrm{NH}_{4}{ }^{+}$against effective tide height. F-values are presented for the model utility test of the slope of each relationship. See Table 1 for treatment abbreviations and levels (see 'Result: Tide height effects' for definition). ${ }^{*} \mathrm{p} \leq 0.05 ;{ }^{* *} \mathrm{p} \leq 0.01 ;{ }^{* * *} \mathrm{p} \leq 0.001$ 


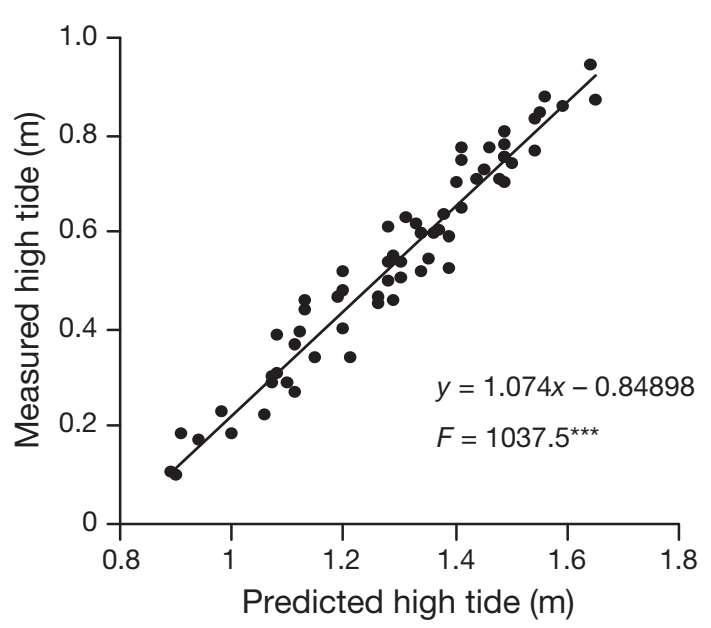

Fig. 6. Linear regression of high tide height in West Falmouth Harbor, as predicted from the XTide program (Flater 1998), against high tide height in Great Sippewissett salt marsh, as measured by HOBO Water Level Loggers. ${ }^{* * *} \mathrm{p}<0.001$

most prominent effects of $\mathrm{N}$ addition was the effect of tide range on export at the highest level of $\mathrm{N}$ addition (XF). The XF plots showed lower export rates at low tide heights and higher export rates at high tide heights (Fig. 7) than the other plots, as suggested by the regression slopes in Fig. 5. However, the exports from XF plots during higher tides so exceeded exports from $\mathrm{C}$ or LF plots that greater amounts of DIN were exported seasonally; total export of $\mathrm{NO}_{3}{ }^{-}$and $\mathrm{NH}_{4}{ }^{+}$ during the fertilization period increased with $\mathrm{N}$ input rate (linear regression using log-transformed values for $\mathrm{NO}_{3}{ }^{-}, \mathrm{NO}_{3}^{-}: \mathrm{p}<0.00, \mathrm{NH}_{4}{ }^{+}: \mathrm{p}=0.01$; without U plots, $\mathrm{NO}_{3}^{-}: \mathrm{p}=0.001, \mathrm{NH}_{4}^{+}: \mathrm{p}=0.02$ ) (Fig. 8), with significance driven by the XF plots.

As a check on the $\mathrm{N}$ exports calculated from the linear regression approach, we used a second (multiplicative) method to estimate $\mathrm{NO}_{3}{ }^{-}$and $\mathrm{NH}_{4}{ }^{+}$export over the period of fertilization. The lowest high tide height for all sampled ebb tides was approximately $25 \mathrm{~cm}$, at which point there was almost no flooding of the marsh surface. Based on the tide record for Great Sippewissett salt marsh, there were 291 high tides $\geq 25 \mathrm{~cm}$ over the fertilization period. Multiplication of the mean export of DIN per tide (Fig. 4) by 291 tides resulted in DIN exports that were comparable to estimates using effective tide height regressions (Table 2).

It is important to differentiate between mean DIN export, which was derived from direct measurements from sampled tides, and extrapolated export, which represents estimates for the entire fertilization period. Both mean DIN export and extrapolated export are estimates of gross DIN export, i.e. they do not consider imports.

These seasonal export predictions, as well as the measured export on individual tides, depend on accurate estimates of the volume of ebb tidal water leaving each plot. Calibrations of the tidal volume model were based upon measured and predicted tides in West Falmouth Harbor for the tides when direct measurements were made. Modeled ebb tidal volumes were higher than values from measurements, with an average ratio of 1.6 (modeled to measured, $\mathrm{SE}=0.2, \mathrm{n}=7$, Fig. 9). The 2 sets of volumetric predictions aligned when predicted Great Sippewissett tide heights were adjusted by approximately $6 \mathrm{~cm}$ (mean factor difference $=1.0$, $\mathrm{SE}=0.1$ ), suggesting that the discrepancy may be in the conversion from tide height predictions in West Falmouth Harbor to those in Great Sippewissett salt marsh. Therefore, to account for variability in tide height conversions such as that due to wind and other meteorological factors, the calibrated model was also used to calculate the Great Sippewissett salt marsh ebb tidal flows for each plot over the growing season, resulting in a lower bound of $\mathrm{N}$ export estimates (data not shown), which were used for calculations of percent $\mathrm{N}$ interception (see below). Because the model was constructed from site-specific measurements, and only one calibration tide could be performed per plot for the flow measurements, the unadjusted modeled volumes were used to provide a conservative measure of $\mathrm{N}$ export from the plots and the proportion of added $\mathrm{N}$ exported. Since the measured volume estimates were less than the modeled volume estimates, $\mathrm{N}$ export based upon the adjusted model was lower, and hence $\mathrm{N}$ interception higher. Actual rates are probably somewhere in between these 2 estimates of $\mathrm{N}$ interception.

\section{Difference in $\mathrm{NO}_{3}{ }^{-}$and $\mathrm{NH}_{4}{ }^{+}$responses to increased fertilization}

Estimates of export over the entire fertilization period showed notable differences in the response of exports of $\mathrm{NO}_{3}{ }^{-}$and $\mathrm{NH}_{4}{ }^{+}$to increased fertilization regimes (Fig. 8). $\mathrm{NH}_{4}{ }^{+}$exports increased linearly with fertilization rate, which contrasted with the accelerated response of $\mathrm{NO}_{3}{ }^{-}$export as $\mathrm{N}$ fertilization rate increased (Fig. 8). As noted above, the significance of these regressions was driven by XF plots. This differential regime resulted in greater export of $\mathrm{NH}_{4}{ }^{+}$than $\mathrm{NO}_{3}{ }^{-}$when $\mathrm{N}$ inputs were low, but comparable $\mathrm{NO}_{3}{ }^{-}$ and $\mathrm{NH}_{4}{ }^{+}$exports from plots receiving the highest $\mathrm{N}$ inputs (Table 3).

\section{Interception capacity of salt marsh plots}

Using the export estimates, it is possible to estimate the fraction of $\mathrm{N}$ exported relative to the amount of $\mathrm{N}$ added over the range of $\mathrm{N}$ loading rates (Table 2); this 

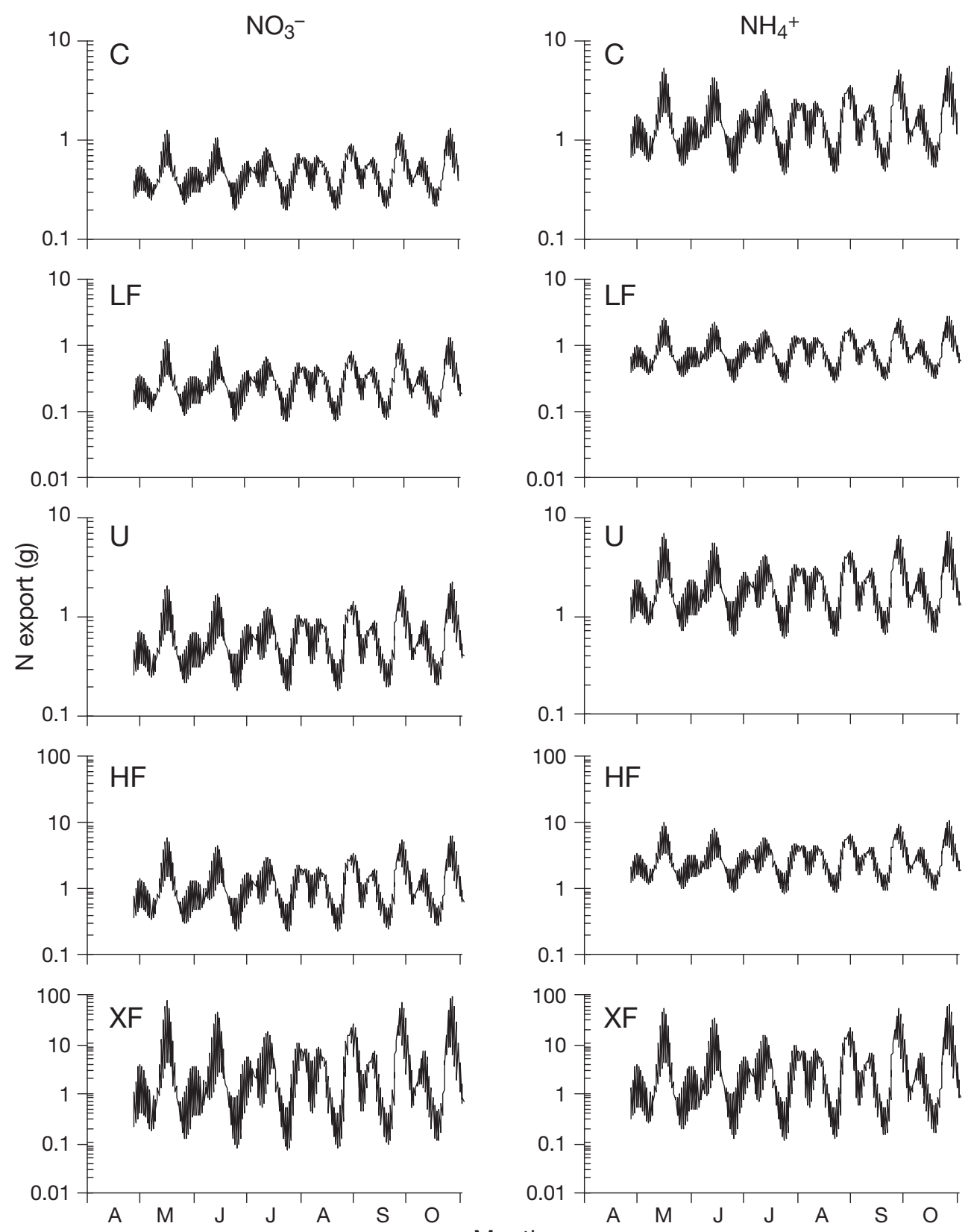

Fig. 7. Export of $\mathrm{NO}_{3}{ }^{-}$and $\mathrm{NH}_{4}{ }^{+}$over the period of fertilization, predicted from fertilization rate and high tide height. Export values are means over the 2 replicate plots per treatment. See Table 1 for treatment abbreviations and levels

export fraction and the interception fraction sum to 1. From each estimate of gross DIN export (as $\mathrm{NO}_{3}{ }^{-}$and $\mathrm{NH}_{4}{ }^{+}$), we first subtracted the mean total DIN export from $\mathrm{C}$ plots, assuming that export from $\mathrm{C}$ plots was a measure of export from natural, unfertilized marshes. This calculation provided an estimate of DIN export attributable to the experimentally added $\mathrm{N}$ for each plot, which could be compared to experimental $\mathrm{N}$ input.

Even though we measured significantly higher exports from plots subject to higher $\mathrm{N}$ additions, the more ecologically significant finding was that DIN export from $\mathrm{N}$-amended plots constituted only a small fraction of $\mathrm{N}$ addition. This low level of $\mathrm{N}$ export, even under very high external loading rates, was evident in estimates obtained from both methods of calculation. Using estimates of $\mathrm{N}$ export from the linear regression method, and the original and unadjusted flux models, percent interception of added $\mathrm{N}$ ranged among treatments from 93.9 to $105.9 \%$; with the multiplicative method, percent interception ranged among treatments 


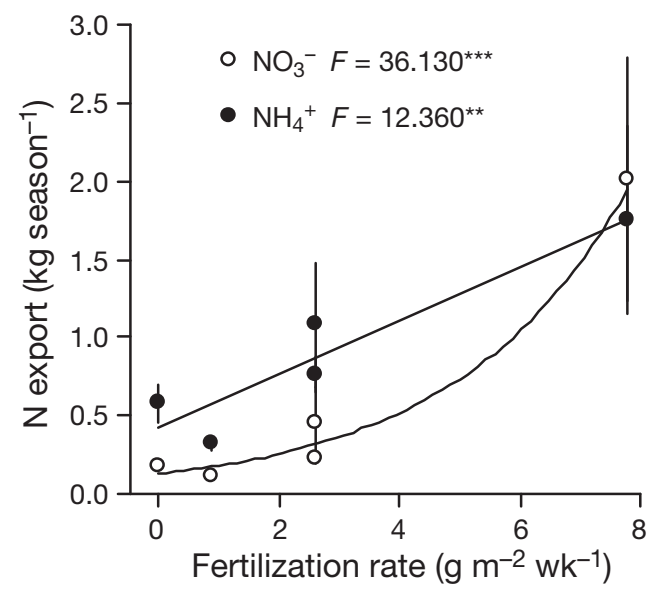

Fig. 8. Total estimated export $( \pm \mathrm{SE})$ of $\mathrm{N}$ as $\mathrm{NO}_{3}{ }^{-}$and $\mathrm{NH}_{4}{ }^{+}$ versus total $\mathrm{N}$ added over the fertilization period. Export values were estimated using linear regression equations relating export and high tide height, by fertilization rate. Mean exports were higher from HF plots than from U plots. See

Table 1 for treatment abbreviations and levels

from 93.3 to $104.8 \%$ (Table 4 ). In both cases, the fraction of the added $\mathrm{N}$ that was exported increased with the level of $\mathrm{N}$ amendment for the more highly fertilized plots. LF plots exported less DIN than the C plots, such that the calculated fraction of the addition that was exported was negative; however, the differences and values involved were small, and treatment $\mathrm{N}$ export was low for all plots.

\section{DISCUSSION}

\section{Net import and export of $\mathbf{N}$ from unfertilized marsh}

The similarity in flood and ebb DIN concentrations for control plots and for plots receiving lower levels of $\mathrm{N}$ amendment is consistent with studies of natural marsh indicating negligible losses of DIN from the

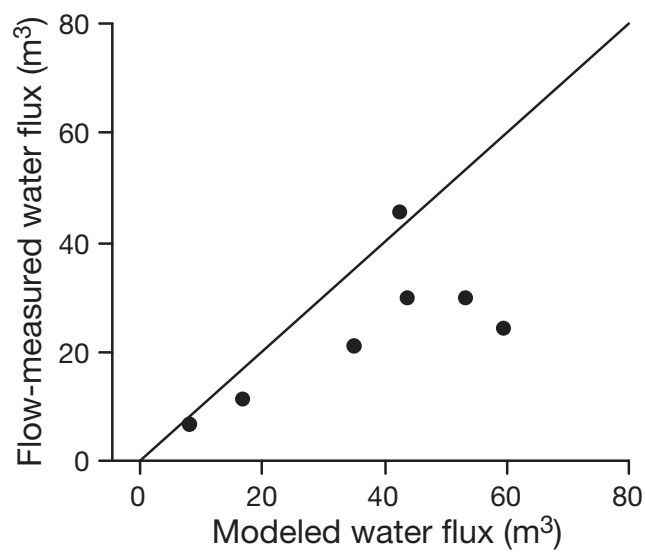

Fig. 9. Ebbing water flux from experimental plots as modeled from elevation data and as calculated from directly measured water flow speeds, October 2008. Values are for the 7 plots for which accurate flow data were obtained

vegetated marsh surface during June and July (Wolaver et al. 1983, Whiting et al. 1989). This suggests that if there are any natural inputs of $\mathrm{N}$ to the salt marsh, such as through atmospheric deposition, elevated tidal $\mathrm{N}$ concentrations or internal $\mathrm{N}$ sources to tidal water, such as leaching from plants, it is entering the $\mathrm{N}$ cycle within the plots and is largely not exported in outgoing tidal waters at this time of year.

\section{Difference in $\mathrm{NO}_{3}{ }^{-}$and $\mathrm{NH}_{4}{ }^{+}$responses to increased fertilization}

Several inferences can be made from the differences among fertilization treatments in the ratios of $\mathrm{NO}_{3}{ }^{-}$to $\mathrm{NH}_{4}{ }^{+}$tidally exported over the experimental period. First, there was greater export of $\mathrm{NH}_{4}{ }^{+}$than of $\mathrm{NO}_{3}{ }^{-}$, except at the highest $\mathrm{N}$ addition, where DIN export was equally divided between these 2 forms. This may suggest that in marsh plots where $\mathrm{N}$ inputs are relatively low, as is the case in a natural system, $\mathrm{NH}_{4}{ }^{+}$

Table 2. N addition and export over the April to October period of fertilization. Fertilizer was applied 10 times over the growing season, approximately biweekly. $\mathrm{N}$ added is the total $\mathrm{N}$ applied over the fertilization period to each plot receiving the specified treatment. Mean $( \pm \mathrm{SE})$ exports $\left(\mathrm{NO}_{3}{ }^{-}, \mathrm{NH}_{4}{ }^{+}\right.$and total dissolved inorganic $\mathrm{N}$ [DIN]) were estimated using linear regression equations describing the relationship between $\mathrm{NO}_{3}{ }^{-}$and $\mathrm{NH}_{4}{ }^{+}$export and effective tide height for each treatment, as well as by multiplying average tidal export of DIN by the number of tides likely to remove DIN during the fertilization period. See Table 1 for treatment abbreviations

\begin{tabular}{|c|c|c|c|c|c|c|c|}
\hline \multirow{2}{*}{$\begin{array}{l}\text { Treatment } \\
\left(\mathrm{g} \mathrm{N} \mathrm{m}^{-2}\right. \\
\left.\mathrm{wk}^{-1}\right)\end{array}$} & \multirow{2}{*}{$\begin{array}{c}\mathrm{N} \\
\text { added } \\
\left(\mathrm{kg}_{\mathrm{plot}}^{-1}\right)\end{array}$} & \multicolumn{2}{|c|}{$\mathrm{NO}_{3}{ }^{-}$export $\left(\mathrm{kg} \mathrm{N}\right.$ plot $\left.^{-1}\right)$} & \multicolumn{2}{|c|}{$\mathrm{NH}_{4}^{+}$export $\left(\mathrm{kg} \mathrm{N}\right.$ plot $\left.^{-1}\right)$} & \multicolumn{2}{|c|}{ DIN export (kg N plot $\left.{ }^{-1}\right)$} \\
\hline & & $\begin{array}{l}\text { Linear } \\
\text { regression }\end{array}$ & $\begin{array}{c}\text { Mean } \\
\text { tidal export }\end{array}$ & $\begin{array}{l}\text { Linear } \\
\text { regression }\end{array}$ & $\begin{array}{c}\text { Mean } \\
\text { tidal export }\end{array}$ & $\begin{array}{l}\text { Linear } \\
\text { regression }\end{array}$ & $\begin{array}{c}\text { Mean } \\
\text { tidal export }\end{array}$ \\
\hline $\mathrm{C}(0)$ & 0.0 & $0.18 \pm 0.03$ & $0.19 \pm 0.37$ & $0.58 \pm 0.12$ & $0.63 \pm 0.36$ & $0.76 \pm 0.14$ & $0.82 \pm 0.51$ \\
\hline $\operatorname{LF}(0.9)$ & 5.5 & $0.11 \pm 0.02$ & $0.16 \pm 0.37$ & $0.32 \pm 0.04$ & $0.40 \pm 0.37$ & $0.43 \pm 0.06$ & $0.56 \pm 0.53$ \\
\hline $\mathrm{U}(2.6)$ & 16.5 & $0.23 \pm 0.03$ & $0.27 \pm 0.36$ & $0.76 \pm 0.11$ & $0.88 \pm 0.37$ & $0.99 \pm 0.14$ & $1.14 \pm 0.52$ \\
\hline $\operatorname{HF}(2.6)$ & 16.4 & $0.46 \pm 0.22$ & $0.59 \pm 0.37$ & $1.08 \pm 0.40$ & $1.33 \pm 0.39$ & $1.54 \pm 0.62$ & $1.93 \pm 0.54$ \\
\hline $\mathrm{XF}(7.8)$ & 49.2 & $2.00 \pm 0.77$ & $1.45 \pm 0.44$ & $1.75 \pm 0.60$ & $1.49 \pm 0.43$ & $3.76 \pm 1.38$ & $2.94 \pm 0.62$ \\
\hline
\end{tabular}


Table 3. Ratio of $\mathrm{NO}_{3}{ }^{-}$export to $\mathrm{NH}_{4}{ }^{+}$export over the April to October period of fertilization. Ratios were calculated using estimates of export derived from linear regression equations describing the relationship between $\mathrm{NO}_{3}{ }^{-}$and $\mathrm{NH}_{4}{ }^{+}$export and effective tide height for each treatment, using the unadjusted tidal volume model, as well as by multiplying average tidal export of dissolved inorganic nitrogen (DIN) by the number of tides likely to remove DIN during the fertilization periods. See Table 1 for treatment abbreviations

\begin{tabular}{|c|c|c|}
\hline \multirow{2}{*}{$\begin{array}{l}\text { Treatment } \\
\left(\mathrm{g} \mathrm{N} \mathrm{m}^{-2} \mathrm{wk}^{-1}\right)\end{array}$} & \multicolumn{2}{|c|}{$-\mathrm{NO}_{3}^{-}: \mathrm{NH}_{4}^{+}$export } \\
\hline & $\begin{array}{l}\text { Linear } \\
\text { regression }\end{array}$ & $\begin{array}{l}\text { Mean tidal } \\
\text { export }\end{array}$ \\
\hline $\mathrm{C}(0)$ & 0.31 & 0.30 \\
\hline $\mathrm{LF}(0.9)$ & 0.36 & 0.40 \\
\hline $\mathrm{U}(2.6)$ & 0.30 & 0.31 \\
\hline $\mathrm{HF}(2.6)$ & 0.43 & 0.44 \\
\hline $\mathrm{XF}(7.8)$ & 1.15 & 0.97 \\
\hline
\end{tabular}

regeneration and possibly leaching from marsh grasses are the major sources; in addition, there may be either effective denitrification or minimal nitrification, such that $\mathrm{NO}_{3}{ }^{-}$is not available to be exported. The lesser importance of $\mathrm{NH}_{4}{ }^{+}$export from highly fertilized plots might also be related to the increased presence of high marsh plant species (Valiela et al. 1985, Hersh 1996, L. Fox et al. unpubl. data); Jordan et al. (1983) found that low marsh sites exported $\mathrm{NH}_{4}{ }^{+}$, whereas high marsh sites actually imported a small amount of $\mathrm{NH}_{4}{ }^{+}$.

Second, because of this increase in the relative importance of $\mathrm{NO}_{3}{ }^{-}$export at XF plots, there was an accelerated response of $\mathrm{NO}_{3}^{-}$export with increasing fertilization rate, which contrasted with the near-linear response of $\mathrm{NH}_{4}{ }^{+}$export (Fig. 8, Tables 2 \& 3). This implies that some biogeochemical mechanism results in the export of proportionally more $\mathrm{NO}_{3}{ }^{-}$, but not $\mathrm{NH}_{4}{ }^{+}$, when large amounts of $\mathrm{N}$ are added. One possible mechanism involves air entry to salt marsh sediments, which occurs when evapotranspiration removes water from the sediment, and also by drainage on creek banks, leading to greater oxidation potentials (Howes et al. 1986). It is possible that increased growth at high fertilization levels causes greater oxidation of the sediments, resulting in accelerated rates of nitrification (Howes et al. 1986, Howes \& Teal 1994). Although denitrification rates have been shown to be substantially higher in high fertilization than control plots (Hamersley \& Howes 2005), denitrification rates may only be able to rise to a point (Valiela et al. 2000). In this case, $\mathrm{NO}_{3}{ }^{-}$from any source, including nitrification, could be exported by tidal waters. This contrasts with whole marsh studies, where it is thought that $\mathrm{NO}_{3}{ }^{-}$is intercepted and $\mathrm{NH}_{4}{ }^{+}$is exported (Nixon 1980, Valiela et al. 2000, Valiela \& Cole 2002). The distinction is thought to stem from consistent differences in $\mathrm{N}$ cycling within the marsh, where emergent marsh is
Table 4. Mean percent interception of dissolved inorganic nitrogen (DIN) over the April to October period of fertilization. Percent interception is the ratio of the difference between DIN loss from the specified treatment plot and the control to the total $\mathrm{N}$ added to the treatment plot, i.e. the amount of added $\mathrm{N}$ that is not exported by tidewater. Percent interception is calculated using estimates of export derived from linear regression equations describing the relationship between $\mathrm{NO}_{3}{ }^{-}$and $\mathrm{NH}_{4}{ }^{+}$export and effective tide height for each treatment, as well as from multiplying average tidal export of DIN by the number of tides likely to remove DIN during the fertilization period. For the linear regression method, estimates from the original and adjusted volume models are presented as upper and lower bounds, with the estimate from the adjusted model in italics ( $\mathrm{SE}$ is presented for treatments with adjustments for both replicate plots). Also shown is percent interception as measured by Valiela et al. (1973). nd: no data. See Table 1 for treatment abbreviations

\begin{tabular}{|c|c|c|c|}
\hline \multirow{2}{*}{$\begin{array}{l}\text { Treatment } \\
\left(\mathrm{g} \mathrm{N} \mathrm{m}^{-2}\right. \\
\left.\mathrm{wk}^{-1}\right)\end{array}$} & \multicolumn{2}{|c|}{$\longrightarrow$ Present study } & \multirow{2}{*}{$\begin{array}{c}\text { Valiela } \\
\text { et al. } \\
1973\end{array}$} \\
\hline & $\begin{array}{l}\text { Linear } \\
\text { regression }\end{array}$ & $\begin{array}{l}\text { Mean tidal } \\
\text { export }\end{array}$ & \\
\hline $\mathrm{LF}(0.9)$ & $102.3-105.9(2.8)$ & $104.8(13.8)$ & $77.2-93.6$ \\
\hline $\mathrm{U}(2.6)$ & $97.7(1.1)-98.6(1.2)$ & $98.1(4.6)$ & nd \\
\hline $\operatorname{HF}(2.6)$ & $95.2(3.9)-96.0(2.0)$ & $93.3(4.7)$ & $59.5-79.7$ \\
\hline XF (7.8) & $93.9(2.8)-99.2$ & $95.7(1.7)$ & nd \\
\hline
\end{tabular}

dominated by internal cycling and creek bottoms are dominated by external inputs and denitrification (Howes et al. 1996).

\section{$\mathrm{N}$ export and interception over the experimental period}

Tidal export of $\mathrm{NO}_{3}{ }^{-}$and $\mathrm{NH}_{4}{ }^{+}$increased with $\mathrm{N}$ addition for all but the LF plots, suggesting that $\mathrm{N}$ export from salt marshes depends to some degree on the amount of $\mathrm{N}$ received. The significance of this trend was driven by the XF plots, which have substantially higher denitrification, biomass and plant percent $\mathrm{N}$. Notably, these plots also are higher in elevation, reducing the amount of time the marsh surface is underwater during each tide. Had this not been the case, we may have seen slightly higher export, in which case the difference between XF and other plots would have been greater. However, longer submersion time would also affect denitrification rates and plant growth.

In spite of significant export of $\mathrm{N}$ from plots receiving higher inputs, overall percent interception of added $\mathrm{N}$ was high for all experimental plots (Table 4), emphasizing the importance of salt marshes in reducing $\mathrm{N}$ inputs to coastal waters. This result is complemented by observations that tidal export of $\mathrm{N}$ from the plots decreased sharply after experimental addition of $\mathrm{N}$ ceased (Fig. 4, right). The degree and rapidity of $\mathrm{N}$ interception is unsurprising in light of recent studies in 
Great Sippewissett. Hamersley \& Howes (2005) injected ${ }^{15} \mathrm{NH}_{4}{ }^{+}$into Great Sippewissett salt marsh sediments underlying Spartina alterniflora and found minimal, non-significant losses of ${ }^{15} \mathrm{~N}$ to overlying tidal water by sediment-water exchange. Similarly, rapid losses of ${ }^{15} \mathrm{~N}$ through coupled nitrification-denitrification and quick incorporation of DIN into salt marsh plant biomass has been observed in natural stands of $S$. alterniflora (White \& Howes 1994, Hamersley \& Howes 2005). These studies further found that $>40 \%$ of the added $N$ was retained in the sediments after $7 \mathrm{yr}$, and the dominant pathway of $\mathrm{N}$ loss was denitrification. The present study corroborates the conclusion that, even on the larger spatial scale of experimental plots, DIN export by emergent marsh is extremely low.

$\mathrm{N}$ interception in experimental plots also occurs by plant uptake, as evidenced by increases in biomass (Valiela et al. 1975, Vince et al. 1981) and percent $\mathrm{N}$ in the tissues of several species of marsh grasses (Vince et al. 1981, Turner et al. 2009). Further visual evidence of this can be found in the still-distinct boundary between fertilized and unfertilized vegetation at the edges of plots (Turner et al. 2009, I. Valiela pers. obs.). Recent findings by Turner et al. (2009) indicate that $\mathrm{N}$ enrichment does not generally lead to belowground organic or inorganic accumulation, although the burial fate of added $\mathrm{N}$ is being further assessed by E. Kinney et al. (unpubl. data). Thus $\mathrm{N}$ interception in experimental plots is likely due to high denitrification rates and incorporation into plant tissue.

On the dates on which DON concentrations were measured, gross DON exports were variable, and there appeared to be no significant differences in DON export associated with the level of $\mathrm{N}$ addition. Nevertheless, DON export tended to be lowest at the highest levels of $\mathrm{N}$ addition, which contrasts with DIN export, which was highest from XF plots. The mechanism for this pattern of DON export is presently unclear, but may relate to inundation time, higher rates of organic matter turnover and/or less immersion of the taller plants in the HF and XF plots versus controls. Whatever the mechanism, the lower DON gross export from $\mathrm{XF}$ plots suggests that adding treatment $\mathrm{N}$ does not increase DON export to coastal systems.

Although the present study examined DIN and DON export from experimental plots, an undetermined $\mathrm{N}$ loss may have occurred via particulate organic $\mathrm{N}$ (PON) export. PON flux varies substantially by tide and the direction of the flux is often inconsistent (Valiela et al. 1978, Wolaver et al. 1983, Whiting et al. 1989). An $\mathrm{N}$ balance constructed for unfertilized marsh plain vegetated with short Spartina alterniflora in Great Sippewissett salt marsh indicated that particulate $\mathrm{N}$ losses were about $1.6 \mathrm{~g} \mathrm{~N} \mathrm{~m}^{-2} \mathrm{yr}^{-1}$ (White \& Howes 1994). Valiela et al. (1978) estimated an annual particulate export from Great Sippewissett salt marsh of $1462 \mathrm{~kg} \mathrm{yr}^{-1}$, which, divided over $483800 \mathrm{~m}^{2}$ of total marsh area (submerged and emergent) (Valiela \& Teal 1979), gives an estimate of $3.0 \mathrm{~g} \mathrm{~N} \mathrm{~m}^{-2} \mathrm{yr}^{-1}$. These estimates are equivalent to 0.50 and $0.95 \mathrm{~kg} \mathrm{~N} \mathrm{yr}^{-1}$ plot $^{-1}$ for unfertilized plots. Thus PON fluxes may be important to coastal waters receiving exports from pristine marshes. $\mathrm{N}$ in particulate form is unavailable for uptake by primary producers, unlike $\mathrm{NO}_{3}{ }^{-}$or $\mathrm{NH}_{4}{ }^{+}$, which have been shown to increase growth of macroalgae (Naldi \& Wheeler 1999, Cohen \& Fong 2004, Teichberg et al. 2008), leading to detrimental effects in eutrophic systems. Thus small DIN export from Namended plots suggests that salt marshes mediate coastal eutrophication by intercepting added $\mathrm{N}$ before it reaches coastal waters in a potentially harmful form.

Our calculations of percent interception of treatment $\mathrm{N}$ may be conservative because of possible overestimates of ebb tidal volume from the unadjusted model, leading to a higher $\mathrm{N}$ export. The difference between modeled and directly measured tidal volumes may be due to several factors. First, the measured flux estimate would be lowered if ebbing water bypassed the measurement point by flooding across the edges of the plot once the main creek is bank full. Although this effect does not seem to occur substantially, it might vary depending on the height of the tide. While this would introduce error, the derived $\mathrm{N}$ export would still be an overestimate, leading to a conservative estimate of percent N interception. Second, as already suggested, error could be introduced into the conversion of Great Sippewissett tide heights from West Falmouth Harbor predictions by variation in weather or wind. This would lead to an overestimate of seasonal DIN export with the volume model, tempered by use of adjusted seasonal tide height predictions which led to a bounded estimate of $\mathrm{N}$ interception (Table 4 ).

Such a low amount of $\mathrm{N}$ exported relative to the high amount of $\mathrm{N}$ added to vegetated marsh plots is a notable result. After more than 3 decades of $\mathrm{N}$ enrichment, these plots have retained their ability to sequester and denitrify added $\mathrm{N}$. The low rates of $\mathrm{N}$ export are lower than earlier estimates at the same site (Valiela et al. 1973), but methodological differences prevent more critical comparison (Table 4). Nonetheless, our measurements of $\mathrm{N}$ interception suggest remarkable adaptation of the salt marsh $\mathrm{N}$ cycle in response to large differences in $\mathrm{N}$ addition over a long period of time, leading to a near complete retention or interception of added $\mathrm{N}$.

The lack of dissolution and export of fertilizer $\mathrm{N}$ is corroborated by the independent observation that after more than 3 decades of experimental $\mathrm{N}$ addition, the edges of the plots remain to within $\sim 25 \mathrm{~cm}$ of the original boundary (Turner et al. 2009). The permanence of the bounds of the experimental plots attests to the lack 
of mobility of $\mathrm{N}$ on the marsh plain, most likely resulting from uptake by edaphic algae or rooted plants, or denitrification. Thus, despite the fact that increased $\mathrm{N}$ input into salt marsh ecosystems leads to increased $\mathrm{N}$ export as $\mathrm{NO}_{3}{ }^{-}$and $\mathrm{NH}_{4}{ }^{+}$, salt marshes maintain the ability to intercept and remove $\mathrm{N}$ even when exposed to decades of $\mathrm{N}$ input.

Acknowledgements. We thank J. Fill, B. Barber and Y. Olsen for participation in fieldwork and laboratory analysis, L. Fox for providing data from her work and A. Giblin and B. Peterson for comments on earlier versions of this manuscript. We thank the 200+ students and interns who helped to maintain the experimental plots over the last several decades. Support for this analysis and for site maintenance was provided by many federal agencies, especially the National Science Foundation (OCE-0453292, DEB-0516430) and, for the past $12 \mathrm{yr}$, through the institutional support of the Coastal Systems Program SMAST-UMD. We are much indebted to E. F. X. Hughes and family for access and permission to use their salt marsh property for our experimental plots.

\section{LITERATURE CITED}

Baden SP, Loo LO, Pihl L, Rosenberg R (1990) Effects of eutrophication on benthic communities including fish: Swedish west coast. Ambio 19:113-122

Brin L (2008) Nitrogen retention and export in experimental salt marsh plots exposed to chronic nutrient addition. MA thesis, Boston University, Boston, MA

Cloern J (2001) Our evolving conceptual model of the coastal eutrophication problem. Mar Ecol Prog Ser 210:223-253

Cohen RA, Fong P (2004) Nitrogen uptake and assimilation in Enteromorpha intestinalis (L.) Link (Chlorophyta): using ${ }^{15} \mathrm{~N}$ to determine preference during simultaneous pulses of nitrate and ammonium. J Exp Mar Biol Ecol 309:67-77

D'Elia CF, Steudler PA, Corwin N (1977) Determination of total nitrogen in aqueous samples using persulfate digestion. Limnol Oceanogr 22:760-774

Dacey JWH, Howes BL (1984) Water uptake by roots controls water table movement and sediment oxidation in short Spartina marsh. Science 224:487-489

Dame RF, Allen DM (1996) Between estuaries and the sea. J Exp Mar Biol Ecol 200:169-185

Flater D (1998) XTide: harmonic tide clock and tide predictor. Available at http://www.flaterco.com/xtide/

Fox L (2007) The effect of nutrient enrichment and sea level rise on salt marsh vegetation. MA thesis, Boston University, Boston, MA

> Hamersley MR, Howes BL (2003) Contribution of denitrification to nitrogen, carbon and oxygen cycling in tidal creek sediments of a New England salt marsh. Mar Ecol Prog Ser 262:55-69

> Hamersley MR, Howes BL (2005) Coupled nitrification-denitrification measured in situ in a Spartina alterniflora marsh with a ${ }^{15} \mathrm{NH}_{4}{ }^{+}$tracer. Mar Ecol Prog Ser 299:123-135

Hersh DA (1996) Abundance and distribution of intertidal and subtidal macrophytes in Cape Cod: the role of nutrient supply and other controls. PhD dissertation, Boston University, Boston, MA

$>$ Howes BL, Goehringer DD (1994) Porewater drainage and dissolved organic carbon and nutrient losses through the intertidal creekbanks of a New England salt marsh. Mar Ecol Prog Ser 114:289-301
Howes BL, Teal JM (1994) Oxygen loss from Spartina alterniflora and its relation to salt marsh oxygen balance. Oecologia 97:431-438

Howes BL, Dacey JWH, Goehringer DD (1986) Factors controlling the growth form of Spartina alterniflora: feedback between above-ground production, sediment oxidation, nitrogen and salinity. J Ecol 74:881-898

Howes BL, Weiskel PK, Goehringer DD, Teal JM (1996) Interception of freshwater and nitrogen transport from uplands to coastal waters: the role of saltmarshes. In: Nordstrom K, Roman C (eds) Estuarine shores: hydrological, geomorphological and ecological interactions. Wiley Interscience, New York, p 287-310

> Jordan TE, Correll DL, Whigham DF (1983) Nutrient flux in the Rhode River: Tidal exchange of nutrients by brackish marshes. Estuar Coast Shelf Sci 17:651-667

McClelland JW, Valiela I (1998) Linking nitrogen in estuarine producers to land-derived sources. Limnol Oceanogr 43: $577-585$

Naldi M, Wheeler PA (1999) Changes in nitrogen pools in Ulva fenestrata (Chlorophyta) and Gracilaria pacifica (Rhodophyta) under nitrate and ammonium enrichment. J Phycol 35:70-77

Nixon SW (1980) Between coastal marshes and coastal waters: a review of twenty years of speculation and research on the role of sale marshes in estuarine productivity and water chemistry. In: Hamilton P, MacDonald KB (eds) Estuarine and wetland processes with emphasis on modeling. Plenum Press, New York, p 437-526

> Rogers J, Harris J, Valiela I (1998) Interaction of nitrogen supply, sea level rise, and elevation on species form and composition of salt marsh plants. Biol Bull 195:235-237

Seitzinger SP (1990) Denitrification in aquatic sediments. In: Revsbech NP, Srensen J (eds) Denitrification in soil and sediment. Plenum Press, New York, p 301-322

Teichberg M, Fox SE, Aguila C, Olsen YS, Valiela I (2008) Macroalgal responses to experimental nutrient enrichment in shallow coastal waters: growth, internal nutrient pools, and isotopic signatures. Mar Ecol Prog Ser 368: $117-126$

Turner RE, Howes BL, Teal JM, Milan CS, Swenson EM, Goehringer-Toner DD (2009) Salt marshes and eutrophication: an unsustainable outcome. Limnol Oceanogr 54: $1634-1642$

Valiela I (1983) Nitrogen in salt marsh ecosystems. In: Carpenter EJ, Capone DG (eds) Nitrogen in the marine environment. Academic Press, New York, p 649-678

Valiela I (1995) Marine ecological processes, 2nd edn. Springer-Verlag, New York

Valiela I, Bowen JL (2002) Nitrogen sources to watersheds and estuaries: role of land cover mosaics and losses within watersheds. Environ Pollut 118:239-248

Valiela I, Cole ML (2002) Comparative evidence that salt marshes and mangroves may protect seagrass meadows from land-derived nitrogen loads. Ecosystems 5:92-102

> Valiela I, Teal JM (1979) The nitrogen budget of a salt marsh ecosystem. Nature 280:652-656

Valiela I, Teal JM, Sass W (1973) Nutrient retention in salt marsh plots experimentally fertilized with sewage sludge. Estuar Coast Mar Sci 1:261-269

> Valiela I, Teal JM, Sass WJ (1975) Production and dynamics of salt marsh vegetation and the effects of experimental treatment with sewage sludge. Biomass, production and species composition. J Appl Ecol 12:973-981

Valiela I, Teal JM, Volkmann S, Shafer D, Carpenter EJ (1978) Nutrient and particulate fluxes in a salt marsh ecosystem: tidal exchanges and inputs by precipitation and ground- 
water. Limnol Oceanogr 23:798-812

Valiela I, Teal JM, Cogswell C, Hartman J, Allen S, Van Etten R, Goehringer D (1985) Some long-term consequences of sewage contamination in salt marsh ecosystems. In: Godfrey P.J, Kaynor ER, Pelczarski S, Benforado J (eds) Ecological considerations in wetlands treatment of municipal wastewaters. Van Nostrand Reinhold, New York, p 301-316

Valiela I, Costa J, Foreman K, Teal JM, Howes B, Aubrey D (1990) Transport of groundwater-borne nutrients from watersheds and their effects on coastal waters. Biogeochemistry 10:177-197

Valiela I, Foreman K, LaMontagne M, Hersh D and others (1992) Couplings of watersheds and coastal waters: sources and consequences of nutrient enrichment in Waquoit Bay, Massachusetts. Estuaries 15:443-457

Valiela I, McClelland J, Hauxwell J, Behr PJ, Hersh D, Foreman K (1997) Macroalgal blooms in shallow estuaries: controls and ecophysiological and ecosystem consequences. Limnol Oceanogr 42:1105-1118

Editorial responsibility: Kenneth Heck Jr., Dauphin Island, Alabama, USA
Valiela I, Cole ML, McClelland J, Hauxwell J, Cebrian J, Joye S (2000) Role of salt marshes as part of coastal landscapes. In: Weinstein MP, Kreeger DA (eds) Concepts and controversies in tidal marsh ecology. Kluwer Academic Publishers, Dordrecht, p 23-38

Vince SW, Valiela I, Teal JM (1981) An experimental study of the structure of herbivorous insect communities in a salt marsh. Ecology 62:1662-1678

White DS, Howes BL (1994) Long-term ${ }^{15} \mathrm{~N}$-nitrogen retention in the vegetated sediments of a New England salt marsh. Limnol Oceanogr 39:1878-1892

Whiting GJ, McKellar HN Jr, Spurrier JD, Wolaver TG (1989) Nitrogen exchange between a portion of vegetated salt marsh and the adjoining creek. Limnol Oceanogr 34: 463-473

Wolaver TG, Zieman JC, Wetzel R, Webb KL (1983) Tidal exchange of nitrogen and phosphorus between a mesohaline vegetated marsh and the surrounding estuary in the lower Chesapeake Bay. Estuar Coast Shelf Sci 16: 321-332

Submitted: June 27, 2009; Accepted: December 17, 2009 Proofs received from author(s): January 25, 2010 